\title{
Analisis Pengaruh Kinerja Keuangan terhadap Profitabilitas Bank Syariah di Indonesia
}

\author{
Heri Sudarsono \\ Universitas Islam Indonesia Yogyakarta \\ email: heri.sudarsono@uii.ac.id
}

\begin{abstract}
This study aimed to analyze the factors affecting the amount of profitability (ROA) provided by Islamic banking in Indonesia. The data which is used is taken from the financial report of the Shari'a Bank during the 2011-2016 periods by using montly financial statement This study uses a Vector Error Correction Model (VECM) to see the long-term effect and response to shock that occur in the studied variables. The result shows that in the long run, the percentage Financing (FIN) and BOPO give a positive siqnifikant effect on the ROA, while third party funds (DPK), percentage profit and loss sharing (TBH), financial to deposit ratio (FDR) has negative and siqnificant effect on the ROA. Sertifikat Bank Indonesia Syariah (SBIS) and non performing finance (NPF) have no significant effect on the ROA. In short run, ROA give a negatif and siqnificant effect on the ROA and FDR give a positif and siqnificant effect, while DPK, FIN, SBIS, TBH, NPF and BOPO have no sinificant effect on the ROA. Therfore, shocks that occur in the ROA, FIN, FDR, NPF dan BOPO positively responded by ROA and will be stable in the long term. While the shocks that occur in the percentage of FDR, SBIS and TBH responded negatively by financing and will be stable in the long term.
\end{abstract}

Keywords: Financing; Return on Asset; Capital Adequacy Ratio; Financing Debet Ratio; Percentage of Profit and Loss Sharing; VECM.

\begin{abstract}
Abstrak: Penelitian ini bertujuan untuk menganalisis faktor-faktor yang memengaruhi profitabilitas (ROA) perbankan syariah di Indonesia. Data yang digunakan data bulanan dari laporan keuangan bank syariah periode 20102015. Penelitian ini mengunakan Vector Error Correction Model (VECM) untuk melihat dampak jangka panjang dan respon terhadap dampak shock pada setiap variabel terhadap pembiayaan. Hasil olah data menunjukkan bahwa FIN dan BOPO berhubungan positif terhadap ROA, sedangkan DPK, TBH, FDR berhubungan negatif terhadap dan ROA SBIS dan NPF tidak berpengaruh terhadap tingkat ROA. Dalam jangka pendek, ROA berhubungan negatif, tetapi FDR terhadap ROA berhubungan positif. Sedangkan DPK, FIN, SBIS, TBH, NPF and BOPO tidak berhubungan dengan pembiayaan. Di lain pihak, respon pembiayan terhadap goncangan yang terjadi terjadi pada ROA, FIN, FDR, NPF dan BOPO direspon positif oleh ROA. Sedangkan respon ROA terhadap goncangan yang terjadi pada FDR, SBIS dan TBH adalah negatif.
\end{abstract}

Kata Kunci: Pembiayaan; Return on Asset; Capital Adequacy Ratio; Financing Debet Ratio; Percentage of Profit and Loss Sharing; VECM.

Economica: Jurnal Ekonomi Islam - Volume 8, Nomor 2 (2017) 


\section{Pendahuluan}

Return on Aset (ROA) atau profitabilitas merupakan rasio yang digunakan untuk mengukur efektivitas manajemen dalam mengelola besaran laba yang diperoleh bank. ROA digunakan untuk mengetahui kemampuan bank dalam mengelola aset untuk menghasilkan laba secara maksimal. Tingkat ROA setiap periode dipengaruhi oleh besaran pembiayaan bank syariah. Perkembangan ROA bank syariah dari tahun 2011 sampai 2016 cenderung mengalami fluktuasi. Gambar 1 menunjukkan bahwa pada tahun 2011, profitabilitas bank syariah sebesar 1,79\% namun kemudian naik pada tahun 2012 menjadi $2.1 \%$. Pada tahun 2014, ROA mengalami penurunan hingga 0,8\%. Turunnya pembiayaan pada tahun 2014 dipengaruhi turunnya besaran pembiayaan pada tahun yang sama sehingga menyebabkan rasio pendapatan terhadap aset turun. Seiring dengan meningkatnya pembiayaan pada tahun 2015, ROA meningkat 2,2 \% di tahun 2015 dan kemudian pada tahun 2016 sebesar $2,27 \%$.

Gambar 1. Perkembangan ROA dari 2011 sampai 2016

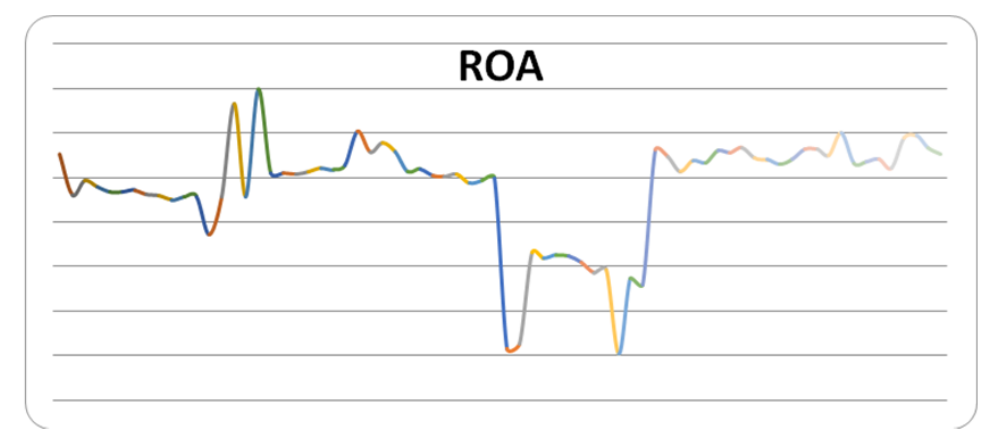

Selama tahun 2011 sampai 2016 perkembangan dana pihak ketiga (DPK) menunjukkan perkembangan yang kurang stabil. Perkembangan DPK dari tahun 2011 sampai 2014 secara nominal mengalami kenaikan tetapi prosentase kenaikan DPK dari tahun 2011 sampai 2014 mengalami 
penurunan. Di tahun 201, DPK 1 sebesar 115, 415 miliar kemudian turun pada tahun 2012 turun 19, 62\% dan 15, 75\% di tahun 2013. Pada tahun 2015 mengalami penurunan sampai 21,56\% atau sebesar Rp 174, 895 miliar dari tahun 2014. Pada tahun 2016, DPK menunjukkan tren naik $15,25 \%$ pada tahun 2016 atau sebesar Rp 206,407 miliar. Fluktuasi DPK lebih banyak dipengaruhi kondisi makro ekonomi, seperti tingkat pendapatan masyarakat, tingkat inflasi, nilai tukar dan kondisi investasi. Faktor internal seperti tingkat bagi hasil, kinerja keuangan bank yang tidak banyak berpengaruh terhadap keputusan mitra untuk melakukan investasi dalam bentuk tabungan, deposito dan giro.

Tingkat DPK akan memengaruhi keputusan manajemen bank syariah untuk menyalurkan pembiayaan. Data statistik perbankan syariah menunjukkan bahwa pada tahun 2011 total pembiayaan yang berhasil dihimpun sebesar Rp. 102.655 miliar dan tren positif terjadi hingga tahun 2014. Namun, pada tahun 2015 nilai pembiayaan turun sebesar Rp 154.527 miliar atau turun sebesar 28, 99\% dari pembiayaan tahun 2013 dengan nilai Rp 184.122. Turunnya DPK pada tahun 2014 dan 2015 disebabkan adanya respon negatif terhadap kenaikan tingkat bagi hasil pada tahun 2014 sebesar 14,02\% dan tahun 2015 sebesar 13,94\%. Ketika TBH pada tahun 2016 turun sebesar 12,92 \%, pembiayaan meningkat sebesar sebesar Rp 178.043 atau $13,20 \%$. Besarnya pembiayaan bank syariah ini sangat dipengaruhi oleh besarnya dana bank yang berasal dari DPK. DPK dipengaruhi oleh tingkat bagi hasil dan dipengaruhi oleh besaran tingkat wadi'ah pada Sertifikat Bank Indonesia Syariah (SBIS).

SBIS ini merupakan jenis surat pembiayaan berjangka waktu pendek dengan sistem wadi'ah. SBIS merupakan alat yang digunakan untuk mengatur nilai uang di pasar melalui mekanisme penyerapan kelebihan uang yang ada di masyarakat. Bila jumlah beredar di masyarakat meningkat, SBIS yang ditawarkan dengan sistem wadi'ah akan lebih tinggi. Bila bonus wadi'ah SBIS tinggi akan menarik bank syariah menyimpan uang di SBIS daripada 
Heri Sudarsono

menyalurkan dalam bentuk pembiayaan. Pada tahun 2011, tingkat SBIS adalah 5.04\%, kemudian mengalami penurunan di tahun 2012 sebesar 4.80\%. Pada tahun 2013 SBIS meningkat sampai 7,22\% dan kemudian turun lagi pada tahun 2014 sebesar 6,90\%. Tingkat SBIS pada dari tahun 2013 mencapai lebih dari $6 \%$ dalam usaha menyerap dana masyarakat. Keadaan ini menyebabkan tingkat pembiayaan bank syariah turun dikarenakan pada tahun 2014 TBH bank syariah naik sampai 14, 02\%. Kenaikan TBH lebih tinggi dibanding tahun 2012 dan tahun 2013 dengan nilai berturut-turut 6,49\% dan $7,08 \%$.

Pergerakan pembiayaan dan DPK selama tahun 2011 sampai 2016 memengaruhi tingkat FDR. Tahun 2013 nilai FDR pada bank syariah mencapai $100.32 \%$, merupakan rasio tertinggi selama lima tahun terakhir. Akhir tahun 2014 nilai FDR pada bank syariah mengalami penurunan sebesar 91,5\% menjadi $8.82 \%$ di tahun 2015. Fungsi intermediasi bank syariah mengalami penurunan pada tahun 2014 dan 2015 ditandai dengan turunnya FDR pada tahun tersebut. Turunnya FDR dipengaruhi oleh turunya rasio jumlah pembiayaan terhadap meningkatnya DPK pada tahun yang sama. Namun manajemen bank dalam usaha menjaga likuditas lebih memilih untuk menurunkan tingkat pembiayaan daripada DPK. Pertimbangan manajemen bank lebih banyak karena kondisi makro ekonomi yang mengarah pada peningkatan pembiayaan bermasalah atau NPF.

Pada tahun 2011 tingkat NPF sebesar 2,52\%, dan tahun 2012 sebesar 2,22\%. Tingkat NPF pada tahun 2013 dan 2014 naik berturut-turut sebesar 2,62\% dan 4.33. Tingkat NPF naik tajam pada tahun 2015 dan 2016 dengan nilai sebesar $8,2 \%$ dan $11.14 \%$. Kenaikan tingkat NPF pada periode 20132014 disebabkan meningkatnya besaran pembiayaan yang ditawarkan bank syariah sebelum tahun 2013 dan pada tahun 2014 besaran pembiayan turun tajam. Turunnya pembiayan bermasalah pada tahu 2014, bukan semata-mata pembiayaan bermasalah meningkat tetapi karena menurunya total pembiayaan bank syariah sehingga menyebabkan rasio pembiayaan 
bermasalah dan total pembiayaan atau NPF meningkat pada tahun 2015. Apabilan NPF meningkat akan menurunkan pendapatan bank dan menurunnya pendapatan bank akan memengaruhi tingkat BOPO.

Semakin kecil rasio BOPO menunjukkan semakin efisien bank syariah dalam mengeluarkan biaya untuk mendapatkan pendapatan. Tingkat BOPO dari tahun 2010 sampai 2016 relatif fluktuatif pada kisaran 70\%-80\%. Tingkat BOPO pada tahun 2010 sebesar 78,41\%, kemudian menurun pada tahun 2012 dan 2013 berturut-turut sebesar 74,75\% dan 78,59\%. Kenaikan BOPO pada tahun 2015 dan 2016 berhubungan dengan turunnya tingkat pembiayaan pada tahun yang sama. Turunnya pembiayaan menyebabkan pendapatan operasional turunnya, di lain pihak beban operasional relatif tetap dibanding pendapatan operasional. Keadaan ini menyebabkan tingkat BOPO pada tahun 2015 meningkat sebesar 88,09\% dan 2016 sebesar 87,09\% dibanding tahun sebelumnya sebesar 79,3\%

Berdasarkan penjelasan di atas, maka permasalahan yang dapat dirumuskan dalam penelitian ini adalah apakah kinerja keuangan berpengaruh terhadap tingkat profitabilitas bank syariah di Indonesia. Untuk mengetahui hal tersebut maka penelitian ini akan mengkaitkan sejauh mana pengaruh kinerja keuangan memengaruhi ROA bank syariah.

\section{Landasan Teori}

Tingkat DPK merupakan komponen terbesar yang digunakan bank syariah untuk menghasilkan pendapatan. Semakin besar DPK digunakan meningkatkan kemampun bank untuk menyalurkan pembiayan pada sektor produktif, konsumtif dan jasa. Besarnya pembiayaan akan meningkatkan peluang bank untuk menghasilkan pendapatan dalam bentuk bagi hasil dan margin. Meningkatnya pendapatan bank akan meningkatkan rasio pendapatan terhadap aset atau ROA bank syariah. Dalam penelitian sebelumnnya hubungan DPK dengan ROA menunjukkan dampak yang beragam. Dalam penelitian Sudiyatno dan Suroso (Sudiyatno and Suroso 
Heri Sudarsono

2010) menemukan bahwa kenaikan DPK memengaruhi kemampuan pembiayaan memengaruhi kenaikan ROA. Dalam penelitian Hanania (Hanania 2015) menunjukkan bahwa dalam jangka panjang DPK berpengaruh negatif terhadap ROA tetapi dalam jangka pendek tidak berpengaruh. Di lain pihak, penelitian Yusuf dan Mahriana (Yusuf and Mahriana 2016) menemukan adanya hubungan negatif antara DPK dengan ROA.

Pembiayaan memiliki potensi lebih besar untuk pendapatan keuntungan dibanding dengan pendapatan bank syariah yang bersumber dari wadîah SBIS, secondary market dan jasa-jasa bank. Oleh karena tingkat pembiayaan bank syariah lebih besar dibanding komponen penghasilkan pendapatan yang lain. Semakin besar pembiayaan yang disalurkan dalam bentuk produktif, konsumtif dan jasa maka peluang untuk memperoleh pendapatan lebih besar. Pendapatan yang tinggi akan meningkatkan rasio keuntungan atas aset bank syariah. Seperti yang telah dijelaskan dalam penelitiannya Hanania (Hanania 2015), Yusuf dan Mahriana (Yusuf and Mahriana 2016) menemukan bahwa secara parsial variabel pembiayaan muḍārabah, mushārakah, dan ijārah berpengaruh signifikan terhadap kemampuan bank syariah untuk menghasilkan pendapatan. Namun, dalam penelitian Amalia (Amalia 2016) menemukan bahwa pembiayaan musyarakah berpengaruh negatif terhadap ROA sedangkan muḍārabah dan murābahah tidak berpengaruh.

SBIS merupakan instrumen moneter yang dikeluarkan bank Indonesia untuk menyerap jumlah uang beredar. Tingkat SBIS akan direspon bank syariah dengan meningkatkan tingkat bagi hasil atau margin kepada mitra. Tingkat bagi hasil atau margin berhubungan positif terhadap DPK tetapi berhubungan negatif terhadap pembiayaan. Semakin tinggi SBIS akan meningkatkan TBH, meningkatnya TBH akan meningkatkan DPK dan menurunkan pembiayaan. Turunnya pembiayaan akan mengurangi pendapatan bank atau menurunkan ROA. Namun dalam penelitian-penelitian sebelumnya ditemukan bahwa SBIS tidak berpengaruh secara tegas terhadap 
ROA. Temuan Ubaidillah (Ubaidillah 2017) menunjukkan bahwa SBIS tidak berpengaruh terhadap besaran ROA. Hasil berbeda di temukan oleh Hanania (Hanania 2015) yang menemukan bahwa SBIS pengaruh positif pembiayaan terhadap ROA.

Semakin tinggi FDR maka semakin tinggi dana yang disalurkan dalam bentuk pembiayaan. Besarnya pembiayaan akan memengaruhi besarnya tingkat keuntungan bank atau akan meningkatkan rasio keuntungan atas aset bank (ROA). Namun demikian, meningkatnya FDR tidak selamanya disebabkan naiknya pembiayaan terhadap DPK akan tetapi bisa disebabkan turunnya DPK terhadap pembiayaan. Oleh karena itu, kenaikan FDR bukan semata-mata naiknya pembiayaan tetapi kesulitan bank untuk mendapatkan pendanaan (DPK). Penelitian-penelitian sebelumnya menemukan hubungan yang beragam seperti dalam penelitian Ubaidillah (Ubaidillah 2017) menunjukkan adanya pengaruh positif signifikan antara FDR terhadap ROA. Di lain pihak, penelitian Alhamditia dan Heykal (Rizkita Alhamditia and Heykal 2013), Armereo (Armereo 2015) dan Yusuf dan Mahriana (Yusuf and Mahriana 2016) menemukan bahwa FDR berhubungan negatif terhadap ROA. Sementara itu, penelitian Sabir et al (Muh. Sabir. M, Muhammad Ali 2012) bertentangan dengan penelitian-penelitian sebelumnya, dimana FDR tidak ada hubungan dengan ROA.

Semakin tinggi kemampuan bank dalam mengelola pembiayaan maka akan semakin rendah NPF bank tersebut. Apabila semakin rendah NPF maka bank mampu memaksimalkan keuntungan dari pembiayaan yang dikeluarkan. Bila keuntungan dapat dimaksimlalkan dari pembiayaan sehingga pembiayaan bermasalah bisa diminimalisir maka bank akan mendapatkan keuntungan secara maksimal. Bila keuntungan meningkat dikarenakan pembiayaan bermasalah bisa ditekan maka tingkat ROA bank akan meningkat. Hasil penelitian Ummah dan Suprapto (Ummah and Suprapto 2015), Ubaidillah (Ubaidillah 2017), Yusuf dan Mahriana (Yusuf and Mahriana 2016), Muhaemin dan Wiliasih (Muhaemin and Wiliasih 2016) 
menemukan bahwa NPF berpengaruh negatif terhadap ROA bank syariah. Di dalam penelitian Sabir et al (Muh. Sabir. M, Muhammad Ali 2012), Wibowo dan Syaichu (Wibowo and Syaichu 2013), Hanania (Hanania 2015), Armereo (Armereo 2015) Mulyaningsih dan Fakhruddin (Mulyaningsih and Fakhruddin 2016) menunjukkan bahwa NPF tidak berpengaruh terhadap ROA.

Semakin besar pembiayaan yang disalurkan kepada mitra akan meningkatkan pendapatan bank. Namun demikian, kinerja manajemen bank tidak hanya diukur dari besar pendapatan tetapi tetapi juga kemampuan dalam mengelola besarnya biaya operasional yang dikeluarkan. Kemampuan bank dalam pengelola biaya operasional untuk memaksimalkan pendapatan operasional dapat diketahui dari besara BOPO. Apabila BOPO meningkat menunjukkan kemampuan bank untuk menghasilkan pendapatan menurun dan menurunya pendapatan berpengaruh terhadap turunnya rasio pendapatan terhadap aset bank. Hasil penelitian Alhamditia dan Heykal (Rizkita Alhamditia and Heykal 2013), Ubaidillah (Ubaidillah 2017) dan Muhaemin dan Wiliasih (Muhaemin and Wiliasih 2016) menunjukkan adanya pengaruh yang negatif antara BOPO terhadap ROA. Tetapi dalam penelitian Yuliani (Yuliani 2007), Sudiyatno dan Suroso (Sudiyatno and Suroso 2010), Sabir et al (Muh. Sabir. M, Muhammad Ali 2012) dan Wibowo dan Syaichu (Wibowo and Syaichu 2013) menunjukkan pengaruh positif BOPO terhadap ROA.

Penilaian kinerja keuangan terhadap kemampuan bank syariah untuk menghasilkan laba sangat bermanfaat bagi bank dan mitra bank. Dengan melihat tren kinerja keuangan mitra bank syariah dapat memutuskan model kebijakan kemitraan dengan bank. ROA merupakan indikator mitra yang digunakan untuk mengukur kemampuan manajemen bank dalam memanfaatkan aktiva yang dimilikinya. Berdasarkan penelitian-penelitian sebelumnya yang berhubungan dengan kinerja keuangan dan ROA menunjukkan hubungan yang berbedaan. Berbedaaan hasil penelitian ini 
disebabkan obyek bank syariah yang diteliti, waktu penelitian, jumlah observasi dan jumlah variabel yang digunakan. Berdasarkan dari hasil penelitian sebelumnya maka dilakukan penelitian tentang ROA dengan variabel independen adalah DPK, FIN, SBIS, TBH, FDR, NPF dan BOPO.

\section{Metode Penelitian}

Data yang digunakan dalam penelitian ini merupakan data sekunder yang berupa data runut waktu (time series). Data dalam penelitian ini diperoleh dari laporan statistik Otoritas Jasa Keuangan (OJK) dari tahun 2011 sampai 2016 serta dokumen lain yang mendukung penelitian ini. Digunakan 2011 sampai 2016 karena alasan kelengkapan jumlah data pada masingmasing variabel yang digunakan. Variabel yang digunakan dalam penelitian ini, yaitu Return On Aset (ROA), Dana Pihak Ketiga (DPK), Pembiayaan (FIN), Sertifikat Bank Indonesia Syariah (SBIS), Tingkat Bagi Hasil (THB), Financial To Debet Rasio (FDR), Non-Performing Finance (NPF) dan Rasio Beban Operasional dengan Pendapatan Operasional (BOPO).

Untuk menghindari regresi palsu (spurious regression) yang disebabkan data tidak stasioner maka perlu uji stasioner. Suatu variabel dikatakan stasioner jika nilai rata-rata dan variansnya konstan sepanjang waktu dan nilai kovarian antara dua periode waktu hanya tergantung pada selisih atau selang antara dua periode waktu tersebut. Uji stasioneritas yang biasa digunakan adalah uji akar unit (unit root test). Penelitian ini mengunakan uji unit root test dengan metode Augmented Dickey Fuller test yang diperkenalkan oleh Dickey-Fuller sebagai modifikasi dari uji unit root Dickey-Fuller.

Untuk melihat kointegrasi variabel dalam penelitian ini dilakukan uji kointegrasi. Pengujian kointegrasi dilakukan pada seluruh variabel dalam persamaan untuk menemukan stasioneritas dalam residual regresi. Penelitian ini mengunakan estimasi maksimum likehood kointegrasi yang diusulkan oleh Johansen untuk menguji apakah ada kointegrasi pada seluruh variabel dalam persamaan. Selain itu uji Johansen digunakan untuk untuk menemukan 
jumlah kointegrasi kelompok vektor. Apabila antar ROA, DPK, FIN, SBIS, TBH, FDR, NPF dan BOPO berkointegrasi, sifat hubungan jangka pendek di antara variabel dapat dinyatakan dalam bentuk model vector error correction model (VECM).

VECM digunakan dalam penelitian ini karena adanya koreksi secara bertahap melalui penyesuaian jangka pendek terhadap deviasi dari model keseimbangan jangka panjang (long run equilibrium model). Dengan demikian VECM dapat digunakan unuk memeriksa hubungan jangka panjang dari kesalahan syarat dan regresi variabel dalam sistem persamaan. Namun, dalam VECM tetap membiarkan keberadaan dinamisasi jangka pendek walaupun spesifikasi VECM merestriksi hubungan jangka panjang variabel-variabel endogen agar konvergen ke dalam hubungan kointegrasinya. Oleh karenanya, VECM dapat mengetahui efek hubungan antar ROA, DPK, FIN, SBIS, TBH, FDR, NPF dan BOPO dalam jangka panjang maupun jangka pendek. Adapun model VECM dalam penelitian ini adalah sebagai berikut :

$$
\begin{aligned}
& \Delta R O A_{t}=a_{1}+\beta_{t}\left(e_{t-1)}\right)+\sum_{i=0}^{m} a_{1, i} \Delta R O A_{t-1}+\sum_{1=0}^{m} b_{1, i} \Delta D P K_{t-1}+\sum_{1=0}^{m} c_{1, i} \Delta F I N_{t-1}+\sum_{1=0}^{m} d_{1, i} \Delta S B I S_{t-1} \\
& +\sum_{i=0}^{m} e_{1, i} \Delta T B H_{t-1}+\sum_{1=0}^{m} f_{1, i} \Delta F D R_{t-1}+\sum_{1=0}^{m} g_{1, i} \Delta N P F_{t-1}+\sum_{1=0}^{m} h_{1, i} \Delta B O P O_{t-1}+\varepsilon_{1 t}
\end{aligned}
$$

dimana ROA adalah profitabilitas; $\beta_{1} \sim \beta_{8}$ adalah tingkat penyesuaian parameter, yaitu faktor penyesuaian koreksi kesalahan jangka panjang; $e_{\mathrm{t}-1}$ adalah syarat kesalahan pra koreksi; DPK adalah dana pihak ketiga; ROA adalah return on aset: SBIS adalah sertifikat Bank Indonesia Syariah; TBH adalah tingkat bagi hasil; FDR adalah financing to deposit rasio; NPF adalah non performing finance; BOPO adalah rasio beban operasional dengan pendapatan operasional; $a_{i} \sim h_{i}$ adalah faktor penyesuaian dinamis jangka pendek; $m$ adalah periode lag untuk semua variabel; $\varepsilon_{1 t} \sim \varepsilon_{8 t}$ adalah white noise.

Analisis Impulse Response Function (IRF) dan Variance Decomposition (VD) diperlukan untuk mengetahui shock variabel ROA, DPK, FIN, SBIS, TBH, 
FDR, NPF dan BOPO terhadap ROA. Pada umumnya analisis IRF diperlukan untuk mengetahui pengaruh shock suatu variabel terhadap variabel itu sendiri dan variabel-variabel lainnya di dalam persamaan. Penelitian ini, IRF menggambarkan dampak dari shock suatu variabel terhadap variabel ROA. Dengan IRF dapat diketahui berapa lama pengaruh shock suatu variabel terhadap ROA. Selain itu, IRF dapat mengetahui variabel manakah yang akan memberi response terbesar terhadap adanya shock.

Variance Decomposition (VD) merupakan bagian dari analisis VECM yang menyediakan perkiraan tentang tingkat kontribusi suatu variabel terhadap perubahan variabel itu sendiri dan variabel lainnya pada beberapa periode mendatang. Penelitian ini mengetahui kontribusi ROA, DPK, FIN, SBIS, TBH, FDR, NPF dan BOPO terhadap ROA. Dengan demikian variabel mana yang diperkirakan akan memiliki kontribusi terbesar terhadap ROA dapat diketahui.

\section{Hasil dan Pembahasan}

\section{Uji Stasioneritas /Unit Root Test}

Berdasarkan hasil uji stasioner diketahui bahwa variabel ROA dan NPF stasioner di level sedangkan variabel DPK, SBIS, TBH, FDR dan BOPO menunjukkan kondisi yang tidak stasioner di tingkat level karena nilai probabilitas kurang dari 5\%. Bila variabel tidak stasioner maka diindikasikan menghasilkan regresi lancung. Untuk menghindari masalah regresi lancung maka data perlu ditransformasi dari tidak stasioner menjadi stasioner melalui uji akar unit dari ADF. Dari proses differensi data dengan uji ADF atau uji derajat integrasi dihasilkan kondisi first difference. Tabel 1 menunjukkan bahwa semua data pada uji ADF pada first difference telah stasioner pada $\alpha$ $=1 \%$. 
Tabel 1. Hasil Uji Akar Unit Level dan First Difference

\begin{tabular}{|c|c|c|c|c|c|c|}
\hline \multirow{2}{*}{$\begin{array}{c}\text { Varia } \\
\text { bel }\end{array}$} & \multicolumn{3}{|c|}{ Level } & \multicolumn{3}{|c|}{ First Difference } \\
\hline & $\begin{array}{c}\text { Dickey Fuller } \\
\text { Test }\end{array}$ & $\begin{array}{l}\text { Proba } \\
\text { bilitas }\end{array}$ & Keterangan & $\begin{array}{l}\text { Dickey } \\
\text { Fuller Test }\end{array}$ & $\begin{array}{l}\text { Proba } \\
\text { bilitas }\end{array}$ & $\begin{array}{l}\text { Ketera } \\
\text { ngan }\end{array}$ \\
\hline ROA & -3.477143 & 0.0115 & Stasioner & -11.76207 & 0.0001 & Stasioner \\
\hline LNDPK & -2.442036 & 0.1342 & $\begin{array}{c}\text { Tidak } \\
\text { Stasioner }\end{array}$ & -8.207062 & 0.0000 & Stasioner \\
\hline LNFIN & -3.008019 & 0.0389 & Stasioner & -7.346396 & 0.0000 & Stasioner \\
\hline SBIS & -1.709822 & 0.4220 & $\begin{array}{c}\text { Tidak } \\
\text { Stasioner }\end{array}$ & -5.740008 & 0.0000 & Stasioner \\
\hline TBH & -2.379636 & 0.1511 & $\begin{array}{c}\text { Tidak } \\
\text { Stasioner }\end{array}$ & -10.26851 & 0.0001 & Stasioner \\
\hline FDR & -1.656910 & 0.4486 & $\begin{array}{c}\text { Tidak } \\
\text { Stasioner }\end{array}$ & -8.645552 & 0.0000 & Stasioner \\
\hline NPF & -1.119149 & 0.7037 & Stasioner & -3.912111 & 0.0033 & Stasioner \\
\hline BOPO & -1.694787 & 0.4295 & $\begin{array}{c}\text { Tidak } \\
\text { Stasioner }\end{array}$ & -13.67703 & 0.0001 & Stasioner \\
\hline
\end{tabular}

\section{Penentuan lag optimum}

Penentuan lag optimal merupakan salah satu permasalahan yang terjadi dalam uji stasioneritas. Uji stasioneritas akan menyebabkan residual dari regresi tidak akan menampilkan proses white noise apabila lag terlalu sedikit. Bila residual regresi tidak menunjukkan proses white noise maka model tidak dapat mengestimasi actual error secara tepat. Penentuan lag digunakan kriteria informasi, seperti kriteria Likehood Ratio (LR), Final Prediction Error (FPE), Akaike Information Criterion (AIC), Shwarz Information Criterion (SC), dan Hannan-Quin Criterion (HQ). Dalam penentuan lag optimal dipilih yang mempunyai LR, FPE, AIC, SC dan HQ yang paling rendah. Tabel 2 menunjukkan bahwa hasil uji lag optimum pada kriteria informasi SC dan HQ pada angka 1 atau lag 1. 
Analisis Pengaruh Kinerja Keuangan...

Tabel 2. Pengujian Lag Optimal

\begin{tabular}{ccccccc}
\hline Lag & LogL & LR & FPE & AIC & SC & HQ \\
\hline 0 & -680.9601 & NA & 0.161150 & 20.87758 & 21.14299 & 20.98246 \\
1 & -205.9427 & 820.4846 & $6.37 \mathrm{e}-07$ & 8.422506 & $10.81122^{*}$ & $9.366401^{*}$ \\
2 & -153.7111 & 77.55608 & $9.87 \mathrm{e}-07$ & 8.779123 & 13.29114 & 10.56203 \\
3 & -77.94559 & 94.13286 & $8.63 \mathrm{e}-07$ & 8.422594 & 15.05791 & 11.04452 \\
4 & 6.112421 & $84.05801^{*}$ & $7.53 \mathrm{e}-07$ & 7.814775 & 16.57339 & 11.27572 \\
5 & 83.21928 & 58.41429 & $1.25 \mathrm{e}-06$ & 7.417598 & 18.29952 & 11.71756 \\
6 & 232.2426 & 76.76959 & $5.32 \mathrm{e}-07^{*}$ & $4.841134^{*}$ & 17.84636 & 9.980115 \\
\hline
\end{tabular}

Uji Stabilitas VAR

Uji stabilitas VAR digunakan untuk menghitung akar-akar dari fungsi polinomial atau yang dikenal roots of charactersitic polynomial. Suatu sistem VAR dikatakan stasioner jika seluruh roots-nya memiliki modulus lebih kecil dari satu dan terletak di dalam unitcircle. Gambar 2 menunjukkan nilai modulus pada model berkisar antara 0.2436- 0.7304 atau masuk dalam lingkaran. Berdasarkan hasil tersebut dapat disimpulkan bahwa model VAR stabil pada panjang sehingga bisa dilakukan uji impulse response dan variance decomposistion pada model ini.

Gambar 2. Uji Stabilitas VAR

Inverse Roots of AR Characteristic Polynomial

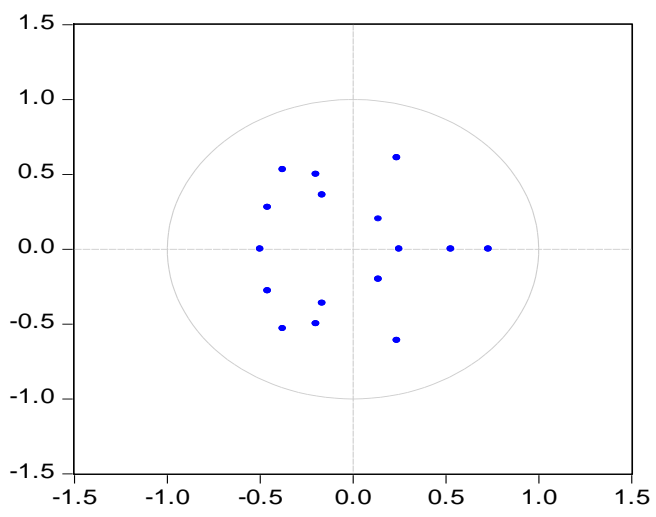

Economica: Jurnal Ekonomi Islam - Volume 8, Nomor 2 (2017) 


\section{Uji Kointegrasi}

Pengujian kointegrasi dilakukan untuk mengetahui hubungan jangka panjang variabel ROA, DPK, FIN, SBIS, TBH FDR, NPF dan BOPO dalam penelitian ini. Salah satu syarat agar tercapai keseimbangan jangka panjang yaitu nilai keseimbangan harus berfluktuasi mendekati nol. Berdasarkan tabel 3 dapat dilihat bahwa pada model terdapat minimal tiga rank kointegrasi dimana trace statistik lebih besar dari critical value 5\%. Dari tabel tersebut menunjukkan bahwa terdapat minimal tiga persamaan kointegrasi yang mampu menerangkan keseluruhan masing-masing model. Artinya terdapat hubungan jangka panjang antara perkembangan ROA dengan faktor-faktor penentunya, yaitu DPK, FIN, SBIS, TBH, FDR, NPF dan BOPO yang hasilnya akan diperjelas pada estimasi VECM, impulse response dan variance decomposition.

Tabel 3. Uji Kointegrasi

\begin{tabular}{lcccc}
\hline $\begin{array}{c}\text { Hypothesized } \\
\text { No. of CE(s) }\end{array}$ & Eigenvalue & $\begin{array}{c}\text { Trace } \\
\text { Statistic }\end{array}$ & $\begin{array}{c}\mathbf{0 . 0 5} \\
\text { Critical Value }\end{array}$ & Prob.** $^{*}$ \\
\hline None * & 0.496211 & 192.5143 & 159.5297 & 0.0002 \\
At most 1 & 0.423025 & 145.2080 & 125.6154 & 0.0018 \\
At most 2 & 0.414057 & 107.2611 & 95.75366 & 0.0064 \\
At most 3 & 0.331834 & 70.37835 & 69.81889 & 0.0451 \\
At most 4 & 0.219351 & 42.55626 & 47.85613 & 0.1437 \\
At most 5 & 0.141308 & 25.46978 & 29.79707 & 0.1453 \\
At most 6 & 0.123609 & 14.9575 & 15.49471 & 0.0601 \\
At most 7 & 0.081340 & 5.853914 & 3.841466 & 0.0155 \\
\hline
\end{tabular}

\section{Hasil Estimasi VECM}

VECM mampu melihat hubungan jangka panjang dan keberadaan dinamisasi jangka pendek variabel-variabel endogen agar konvergen ke dalam hubungan kointegrasinya. Model VECM sebagai model terbaik 
berdasarkan kriteria goodness of fit yang harus dimiliki suatu model. Tabel 4 merupakan hasil estimsi VECM perkembangan ROA yang memperlihatkan hubungan antar variabel pada jangka panjang. Dapat terlihat bahwa variabel yang memengaruhi ROA bank syariah dalam jangka panjang adalah DPK dan TBH, sementara itu FDR pada lag-1 berpengaruh negatif terhadap tingkat ROA. Di lain pihak, FIN pada lag-1 menunjukkan hubungan positif terhadap tingkat ROA.

Tabel 4. Hasil Regresi Jangka Panjang

\begin{tabular}{|c|c|c|c|}
\hline \multirow[b]{2}{*}{ Cointeg Eq: } & \multicolumn{3}{|c|}{ LOG(FIN(-1)) } \\
\hline & & Std Error & t stat \\
\hline $\mathrm{D}(\mathrm{ROA}(-1))$ & 1.000 .000 & & \\
\hline D(LOG(DPK(-1))) & -1.211 .318 & -527.286 & {$[-2.29727]^{*}$} \\
\hline $\mathrm{D}(\operatorname{LOG}(\mathrm{FIN}(-1)))$ & 1.151 .332 & -394.009 & [ 2.92209]* \\
\hline D(LOG(SBIS(-1))) & 0.005529 & (0.19384) & [0.02852] \\
\hline $\mathrm{D}(\mathrm{TBH}(-1))$ & -0.021086 & $(0.00916)$ & {$[-2.30199]^{*}$} \\
\hline $\mathrm{D}(\mathrm{FDR}(-1))$ & -0.117371 & (0.02398) & {$[-4.89525]^{*}$} \\
\hline$D(N P F(-1))$ & -0.092545 & $(0.25874)$ & {$[-0.35767]$} \\
\hline $\mathrm{D}(\mathrm{BOPO}(-1))$ & 0.206243 & $(0.02434)$ & {$[8.47340]^{*}$} \\
\hline C & 0.023540 & & \\
\hline
\end{tabular}

Dari hasi regresi jangka panjang menunjukkan DPK berhubungan negatif dengan ROA, bila ada kenaikan DPK sebesar 1\% maka ROA akan turun sebesar $0.2062 \%$. Kondisi ini bisa diartikan bahwa tingkat DPK tidak memengaruhi manajemen bank syariah untuk meningkatkan besaran pembiayaan sehingga kenaikan DPK tidak berpengaruh langsung terhadap ROA. Sepanjang tahun 2011 sampai 2016, tren DPK mengalami tren menurun yang cukup tajam pada tahun 2014-2015. Sedangkan tren ROA menunjukkan kondisi yang relatif stabil dari tahun 2011 sampai 2016. Kondisi DPK dan ROA yang memiliki tren yang berbeda pada tahun pengamatan menunjukkan 
bahwa tingkat DPK tidak langsung direspon oleh tingkat ROA. Hal ini menunjukkan bahwa pendapatan bank syariah tidak semata-mata dipengaruhi oleh besaran DPK. Hubungan negatif antara DPK dan ROA pernah ditemukan oleh Hanania (Hanania 2015) dalam jangka panjang, tetapi dalam jangka pendek tidak berpengaruh. Demikian pula dengan penelitian Yusuf dan Mahriana (Yusuf and Mahriana 2016)menemukan adanya hubungan negatif antara DPK dengan ROA.

Tingkat pembiayaan meningkatkan pendapatan bank syariah yang akan memengaruhi secara langsung kenaikan pendapatan bank syariah. Kenaikan pendapatan bank syariah meningkatkan tingkat ROA di masa pengamatan. Periode 2011 sampai 2016 menunjukan bahwa kenaikan 1\% pembiayaan direspon positif oleh ROA dengan kenaikan sebesar $1.151332 \%$. Walaupun tren pembiayaan sempat turun pada tahun 2014-2015 namun turunnya pembiayaan tidak banyak memengaruhi besarnya pendapatan bank syariah. Hal ini bisa terjadi dikarenakan sumber pendapatan bank syariah tidak hanya dari pendapatan pembiayaan tetapi juga berasal dari sumber lain, seperti layanan jasa keuangan, ATM, letter of credit, bank garansi dan sebagainnya. Hasil yang sama ditemukan oleh Hanania (Hanania 2015), dan Yusuf dan Mahriana (Yusuf and Mahriana 2016) bahwa pembiayaan memengaruhi besarnya tingkat ROA bank syariah.

Kebijakan BI menyerap jumlah uang beredar melalui penawaran SBIS tidak berpengaruh terhadap kenaikan ROA bank syariah. SBIS tidak bisa langsung memengaruhi tingkat ROA tetapi SBIS memengaruhi ROA melalui besaran prosentase TBH. TBH memengaruhi tingkat pembiayaan dan tingkat pembiayaan memengaruhi besaran pendapatan bank syariah. Pendapatan yang diperoleh bank syariah akan memengaruhi tingkat ROA. Namun tidak selamanya pembiayaan mampu merespon langsung tingkat TBH karena pembiayaan yang menggunakan skim jual beli kurang responsif terhadap tingkat TBH. Di lain pihak, faktor eksternal ekonomi makro sering digunakan manajemen bank syariah untuk menghitung risiko dalam menyalurkan 
pembiayaan. Penelitian Ubaidillah (Ubaidillah 2017) menemukan hasil yang sama bahwa tingkat SBIS tidak berpengaruh terhadap tingkat ROA.

Tingkat bagi hasil berpengaruh negatif terhadap ROA yang artinya kenaikan 1\% TBH akan memengaruhi turunnya ROA sebesar $-0.0210 \%$. Kenaikan TBH meningkatkan beban mitra yang mengajukan pembiayaan yang mengunakan skim bagi hasil. Namun TBH tidak hanya memengaruhi beban mitra yang mengajukan pembiayaan dengan skim bagi hasil tetapi juga pembiayaan jual beli. Tingkat margin dan bagi hasil dalam pembiayaan biasanya equivalennya tidak jauh berbeda karena indikator penentukan bagi hasil dan margin hampir sama, seperti beban operasional, tingkat inflasi dan tingkat bunga. Apabila ada kenaikan TBH diikuti meningkatnya margin pembiayaan dan keadaan tersebut menurunkan keinginan mitra untuk mengajukan pembiayaan Kenaikan TBH akan meningkat pembiayaan apabila kenaikan TBH tidak lebih tinggi dengan kenaikan tingkat suku bunga dan beban risiko pembiayaan yang dihadapi mitra lebih rendah dari bank konvensional risiko.

Semakin tinggi rasio pembiayaan terhadap pendanaan (FDR) menunjukkan prosentase besarnya pendanaan yang disalurkan dalam bentuk pembiayaan. Apabila semakin besar FDR menunjukkan besarnya kemampuan manajemen bank syariah dalam mengelola DPK untuk meningkatkan pendapatan dari pembiayaan disalurkan. Apabila semakin tinggi FDR menyebabkan ROA semakin menurun menunjukkan bahwa manajemen bank kurang mampu mengoptimalkan dana yang dimiliki untuk disalurkan pada pembiayaan yang menguntungkan. Penelitian ini menemukan bahwa dalam jangka panjang FDR berpengaruh negatif terhadap tingkat ROA dimana kenaikan 1\% FDR menurunkan ROA sebesar -0.1173\%. Temuan ini sesuai dengan penelitian Armereo (Armereo 2015) dan Yusuf dan Mahriana (Yusuf and Mahriana 2016) bahwa FDR berhubungan negatif terhadap ROA. Hasil negatif ini dipengaruhi karena pergerakan FDR selama 
Heri Sudarsono

periode 2011 sampai 2016 yang cenderung meningkat, sedangkan pergerakan ROA relatif konstan selama periode pengamatan.

Perkembangan NPF di tahun 2011 sampai 2016 tidak memengaruhi pergerakan ROA bank syariah. Hasil regresi jangka panjang menunjukkan bahwa NPF tidak berpengaruh signifikan terhadap tingkat ROA. Hal ini disebabkan manajemen bank syariah kurang mempertimbangkan besaran NPF untuk menentukan kebijakan penyaluran pembiayaan kepada mitra. Kemampuan manajemen bank yang berhasil mengendalikan NPF selama periode penelitian menjadi alasan NPF tidak memengaruhi tingkat pembiayaan. Walaupun pada tahun 2015, tren kenaikan NPF lebih dari $10 \%$ namun kenaikan ini disebabkan bukan karena meningkat pembiayaan bermasalah tetapi karena menurunnya pembiayaan yang disalurkan bank syariah. Penelitian sebelumnya menunjukkan hasil yang sama dengan penelitin ini, dimana Sabir et al (Muh. Sabir. M, Muhammad Ali 2012), Wibowo dan Syaichu (Wibowo and Syaichu 2013), Hanania (Hanania 2015), Armereo (Armereo 2015) Mulyaningsih dan Fakhruddin (Mulyaningsih and Fakhruddin 2016) menemukan bahwa NPF tidak berpengaruh terhadap terhadap tingkat ROA.

Dari hasil regresi jangka panjang diketahui bahwa bila kenaikan tingkat BOPO sebesar 1\% BOPO akan meningkatkan ROA sebesar $0.2062 \%$. Hasil ini berbeda dengan hipotesis yang menyatakan bahwa BOPO berpengaruh negatif terhadap ROA. Namun dari penelitian sebelumnya yang dilakukan oleh Yuliani (Yuliani 2007) Sudiyatno dan Suroso (Sudiyatno and Suroso 2010), Sabir et al (Muh. Sabir. M, Muhammad Ali 2012) dan Wibowo dan Syaichu (Wibowo and Syaichu 2013) menemukan bahwa BOPO berpengaruh positif terhadap ROA. Tingkat BOPO menjadi pedoman bagi manajemen bank untuk memengaruhi ROA melalui pembiayaan, dan pembiayaan yang akan menurunkan rasio biaya operasional terhadap pendapatan operasional bank syariah. Apabila pendapatan bank syariah naik dengan asumsi bahwa biaya operasional tetap maka BOPO akan menurun dan ROA akan naik. Hubungan 
positif antara BOPO dengan ROA bisa dimaknai bahwa manajemen bank syariah mampu mengelola biaya operasional yang secara efisiensi untuk memaksimal ROA.

\section{Hasil VECM (Persamaan Jangka Pendek/Short Term Equation)}

Dalam jangka pendek koefisien persamaan kointegrasi sebesar 0.0000113 signifikan pada $\alpha=1 \%$, ini adalah koefisien speed of adjusment to equilibrium yang bermakna setiap bulan kesalahan dikoreksi sebesar 0,000113\% menuju target optimal ROA.

Tabel 5. Persamaan Jangka Pendek

\begin{tabular}{llll}
\hline \multirow{2}{*}{ Error Correction: } & \multicolumn{3}{c}{ D(LOG(FIN)) } \\
\cline { 2 - 4 } & & \multicolumn{3}{c}{ Std Error } & t-test \\
\hline CointEq1 & 0.000113 & $(0.13117)$ & {$[0.00086]$} \\
D(ROA(-1),2) & -0.569264 & $(0.13055)$ & {$[-4.36041]^{*}$} \\
D(LOG(DPK(-1)),2) & 3.854 .904 & -310.757 & {$[1.24049]$} \\
D(LOG(FIN(-1)),2) & 0.157423 & -273.327 & {$[0.05760]$} \\
$D(\operatorname{LOG}(\mathrm{SBIS}(-1)))$ & -0.239338 & $(0.24198)$ & {$[-0.98910]$} \\
$D(T B H(-1))$ & -0.002836 & $(0.00590)$ & {$[-0.48045]$} \\
$D(F D R(-1))$ & 0.047893 & $(0.01969)$ & {$[2.43253]^{*}$} \\
D(NPF(-1)) & 0.256833 & $(0.19605)$ & {$[1.31005]$} \\
D(BOPO(-1)) & -0.020930 & $(0.01667)$ & {$[-1.25588]$} \\
$C$ & 0.000544 & $(0.06663)$ & {$[0.00816]$} \\
\hline
\end{tabular}

Nilai kointegrasi sebesar 0,000113 yang signifikan pada tingkat $1 \%$ menunjukkan adanya mekanisme penyesuaian dari jangka pendek menuju jangka panjang. Pada persamaan jangka pendek diketahui variabel yang memengaruhi tingkat ROA dalam jangka pendek adalah ROA lag 1; dan FDR lag-1; sementara DPK, FIN, SBIS, TBH, FDR, NPF dan BOPO tidak berpengaruh secara signifikan. Berbeda dengan jangka panjang dimana FDR berhubungan 
negatif tetapi dalam jangka pendek berhubungan positif. Untuk lebih memperjelas hubungan antara ROA, DPK, FIN, SBIS, TBH, FDR, NPF dan BOPO terhadap ROA dalam jangka panjang dan jangka pendek dapat disimak pada analisis impulse response dan variance decomposition.

\section{IRF (Impulse Response Function)}

Sumbu vertikal pada gambar IRF menunjukkan standar deviasi yang digunakan untuk mengukur seberapa besar respon yang akan diberikan oleh DPK, FIN, SBIS, TBH, FDR, NPF dan BOPO apabila terjadi goncangan terhadap ROA. Sedangkan, sumbu horizontal menunjukkan lamanya waktu respon jika ada goncangan pada ROA. Bila respon ROA di atas sumbu horizontal menunjukkan bahwa goncangan akan memberikan pengaruh yang positif. Sebaliknya apabila respon ROA dibawah sumbu horizontal menunjukkan bahwa goncangan berpengaruh negatif. Gambar 3 menunjukkan respon ROA terhadap variabel ROA, DPK, FIN, SBIS, TBH, FDR, NPF dan BOPO. 
Analisis Pengaruh Kinerja Keuangan...

\section{Gambar 3. Hasil Impulse Response Function}

Response to Cholesky One S.D. Innovations

Response of $D(R O A)$ to $D(R O A)$

Response of $D(R O A)$ to $D(L O G(D P K))$
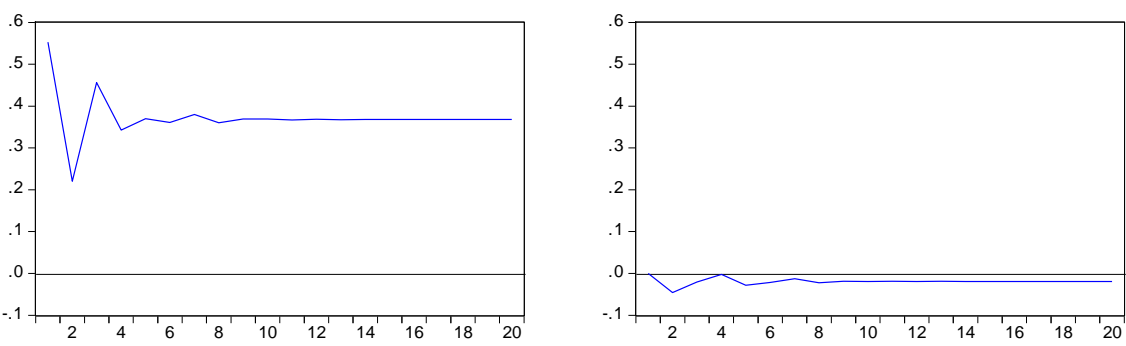

Response of $D(R O A)$ to $D(L O G(F \mid N)$ )

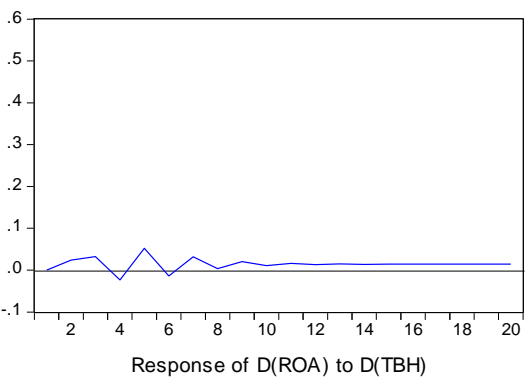

Response of $D(R O A)$ to $D(S B I S)$
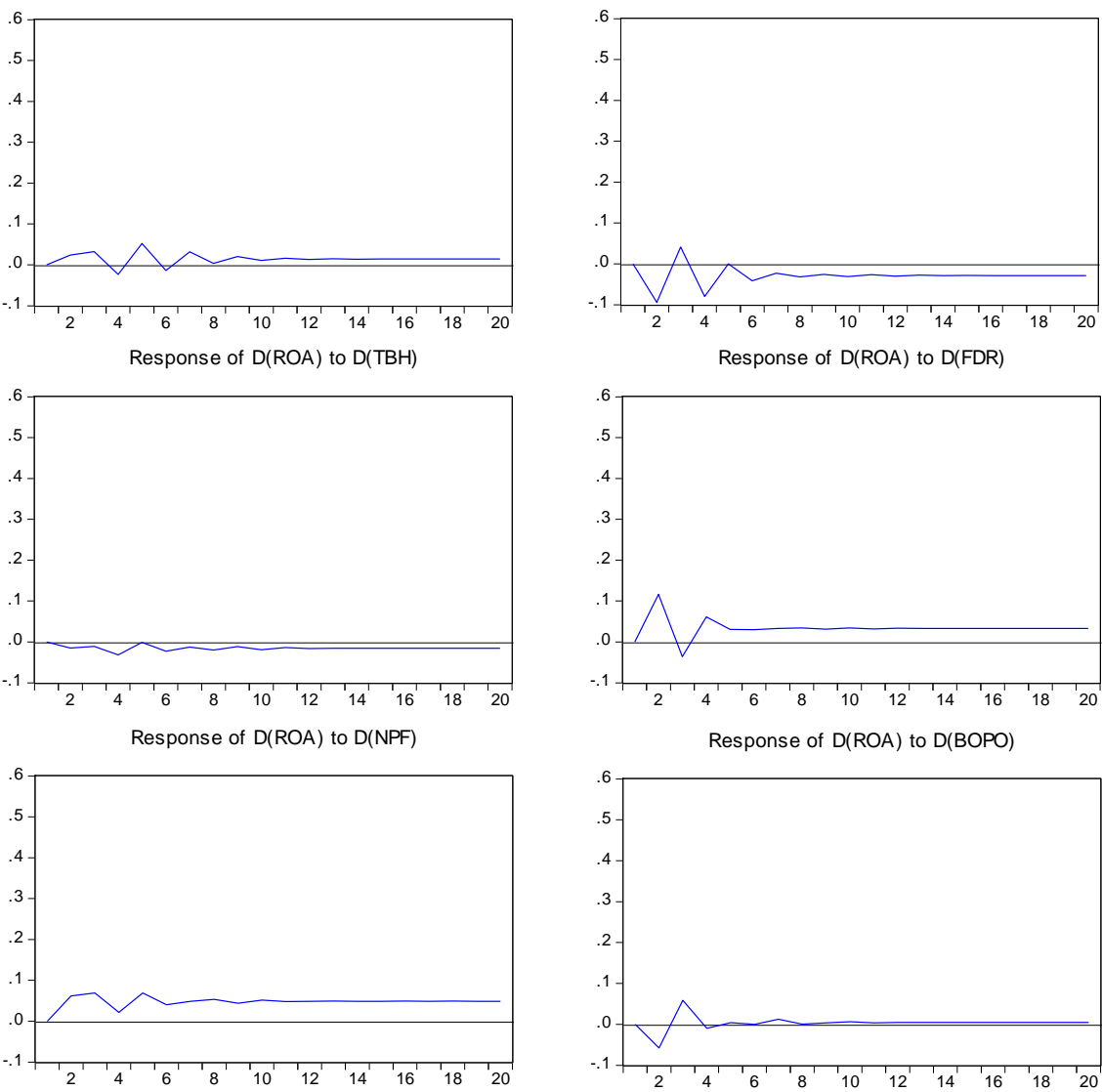

Economica: Jurnal Ekonomi Islam - Volume 8, Nomor 2 (2017) http://journal.walisongo.ac.id/index.php/economica 
Heri Sudarsono

Analisis IRF dengan ROA sebagai response menyimpulkan bahwa di dalam 20 tahun mendatang, respon tertinggi adalah respon ROA terhadap ROA itu sendiri, yang diperkirakan akan stabil pada standar deviasi sembilan. IRF tersebut menunjukkan bahwa pada saat ada goncangan pada ROA, maka ROA itu sendiri akan merespon positif sebesar $5.55 \%$ pada bulan pertama dan kemudian turun pada bulan kedua sebesar 2,20\% dan pada bulan ketiga naik sebesar 4,55\%. Kondisi stabil terjadi mulai pada bulan keempat walaupun terjadi goncangan kecil pada bulan berikutnya sampai pada bulan sembilan dan seterusnya pada kisaran 3,69\%

Respon negatif ROA terhadap goncangan yang terjadi pada DPK ditunjukkan pada bulan kedua sebesar 0,45\%. Respon negatif berlanjut pada bulan ketiga dengan nilai sebesar $0,20 \%$, pada bulan keempat sempat direspon negatif sampai $0,02 \%$, namun pada bulan kelima naik kembali dengan respon sebesar $0,27 \%$. Respon ROA mencapai posisi stabil mulai pada bulan sembilan berkisar pada 0,18\%. Berbeda dengan respon terhadap DPK, goncangan pembiayaan cenderung direspon positif oleh ROA. Pada awalnya ROA memberikan respon negatif terhadap goncangan pada pembiayaan di bulan kedua sebesar 0,24\%. Pada bulan keempat respon ROA negatif terhadap pembiayaan sebesar 0,23\%, namun pada bulan kelima ROA memberi respon positif sebesar 0,52\%. Dan kembali negatif. Pada bulan ketiga sampai bulan keenam respon ROA terhadap pembiayaan fluktuatif pada garis standar deviasi. Keadaan stabil ketika pada bulan ke-10 dengan respon ROA terhadap pembiayaan sebesar $0,10 \%$

Respon negatif ROA terhadap SBIS terjadi pada bulan kedua sebesar $0,94 \%$ dan respon positif ROA terhadap SBIS terjadi pada bulan ketiga sebesar $0,41 \%$. Kemudian respon negatif kembali terjadi pada bulan keempat dengan nilai sebesar $0,79 \%$, respon negatif ROA terhadap goncangan SBIS terus terjadi hingga akhir periode. Respon ROA terhadap goncangan TBH menunjukkan tren yang hampir sama dengan SBIS. Walaupun pada respon ROA terhadap SBIS sangat fluktuatif dibanding dengan respon ROA terhadap 
TBH. Dan, goncangan TBH tidak direspon ROA seagresif respon yang ditunjukkan terhadap goncangan SBIS. Seperti diketahui respon negatif ROA terhadap goncangan TBH sebesar 0,15\% terjadi pada bulan kedua. Kemudian, respon ROA pada bulan-bulan berikutnya terhadap TBH menunjukkan nilai negatif. Kondisi stabil terjadi pada bulan ketujuh dengan respon ROA terhadap sebesar $0,12 \%$.

Pada awal bulan ROA belum memberi respon terhadap goncangan yang terjadi di FDR. Respon positif ROA terhadap goncangan yang terjadi pada FDR terjadi bulan ke-2 dengan tingkat 1,16\% kemudian goncangan FDR pada bulan ketiga menyebabkan ROA merespon negatif sebesar 0,36\%. Namun respon ROA pada bulan keempat terhadap goncangan FDR positif sebesar $0,60 \%$ dan respon positif ROA terjadi pada bulan-bulan berikutnya. Respon ROA terhadap goncangan FDR mencapai posisi stabil mulai pada bulan kelima dengan nilai respon pada tingkat 0,30\%. Seperti halnya respon terhadap FDR, ROA juga merespon posistif terhadap muncul goncangan pada NPF selama periode penelitian. Respon positif ROA di awali pada bulan kedua sebesar $0,61 \%$, kemudian disusul bulan ketiga, keempat dan kelima berturut adalah 0,69\%, 0,21\%, dan 0, 68\%. Respon ROA mencapai pada kondisi stabil pada tingkat $0,5 \%$ pada bulan kesepuluh.

ROA belum memberikan respon terhadap goncangan pada BOPO di bulan pertama. Respon negatif mulai ditunjukan oleh ROA pada bulan kedua sebesar 0,57\%. Namun pada bulan ketiga respon ROA terhadap BOPO menjadi positif dengan tingkat respon sebesar $0,58 \%$. Pada bulan keempat respon ROA negatif sebesar 0,09\% dan pada bulan kelima positif sebesar $0,03 \%$. Respon positif ROA dalam posisi stabil mulai terjadi pada bulan ketujuh dengan nilai respon sebesar $0,12 \%$ dan nilai respon relatif berikutnya menurun sampai akhir pengamatan. 
Heri Sudarsono

\section{Forecast Error Variance Decomposition (FEVD)}

Variance Decomposition (VD) untuk mengetahui kontribusi suatu variabel ROA, DPK, FIN, SBIS, TBH, FDR, NPF dan BOPO terhadap perubahan ROA pada beberapa periode mendatang. Tabel 6, analisis VD menunjukkan bahwa variabel yang diperkirakan akan memiliki kontribusi paling besar terhadap ROA pada sepuluh bulan kedepan adalah ROA sendiri dengan ratarata kontribusi per tahun sebesar 93,65\%, yang diikuti oleh kontribusi FDR sebesar 1,95\%, SBIS sebesar 1, 65\%, NPF sebesar 1,30\%, BOPO sebesar 0,64\%, FIN sebesar 0,36\%, DPK sebesar 0,33\% dan TBH sebesar 0,14\% yang mendekati nol persen.

Tabel 6. Variance Decomposition of ROA

\begin{tabular}{cccccccccc}
\hline Period & S.E. & D(ROA) & D(LOG(DPK)) & D(LOG(FIN)) & D(SBIS) & D(TBH) & D(FDR) & D(NPF) & D(BOPO) \\
\hline 1 & 0.552663 & 100.0000 & 0.000000 & 0.000000 & 0.000000 & 0.000000 & 0.000000 & 0.000000 & 0.000000 \\
2 & 0.621596 & 91.58599 & 0.536271 & 0.151296 & 2.300534 & 0.059046 & 3.518002 & 0.994236 & 0.854629 \\
3 & 0.779166 & 92.53376 & 0.409036 & 0.270247 & 1.747445 & 0.057051 & 2.455466 & 1.422120 & 1.104870 \\
4 & 0.858323 & 92.18767 & 0.337800 & 0.298451 & 2.307432 & 0.183210 & 2.527066 & 1.234445 & 0.923928 \\
5 & 0.939572 & 92.44133 & 0.370512 & 0.556189 & 1.925618 & 0.153039 & 2.214414 & 1.566131 & 0.772765 \\
6 & 1.009042 & 92.91329 & 0.368588 & 0.500975 & 1.839139 & 0.183652 & 2.008470 & 1.515867 & 0.670023 \\
7 & 1.080807 & 93.35602 & 0.335443 & 0.524083 & 1.647745 & 0.173298 & 1.843611 & 1.522348 & 0.597452 \\
8 & 1.141775 & 93.58733 & 0.338894 & 0.470502 & 1.555025 & 0.184721 & 1.742999 & 1.585147 & 0.535381 \\
9 & 1.201903 & 93.90313 & 0.329258 & 0.453309 & 1.449270 & 0.175350 & 1.640585 & 1.564996 & 0.484098 \\
10 & 1.259604 & 94.09135 & 0.322637 & 0.420028 & 1.380573 & 0.183144 & 1.566509 & 1.592213 & 0.443550 \\
\hline
\end{tabular}

Dari hasil rata-rata persentase pada masing-masing variabel tersebut dapat diketahui bahwa FDR memiliki kontribusi terbesar disusul SBIS, NPF, BOPO, FIN, DPK dan yang terakhir adalah TBH dalam memengaruhi besarnya ROA pada bank syariah. Rendahnya kontribusi DPK dan TBH terhadap ROA menunjukkan bahwa manajemen bank syariah kurang memperhatikan besaran DPK dan TBH untuk menentukan kebijakan dengan tujuan meningkatkan ROA. Di lain pihak, manajemen bank syariah lebih memperhatikan besaran kontribusi SBIS, NPF, BOPO dan FIN dalam menentukan besarnya pendapatan untuk memengaruhi tingkat ROA. 
Dilihat dari tren setiap periode pada variance decomposition menunjukkan bahwa tren kontribusi ROA terhadap ROA pada bukan pertama menunjukkan nilai 100\% kemudian pada periode kedua sebesar $91,58 \%$ dan pada periode berikutnya mengalami kenaikan setiap bulan hingga akhir pengamatan. Hal ini memperlihatkan bahwa tingkat ROA saat ini dipengaruhi tingkat ROA pada masa lalu. Keadaan berbeda pada SBIS yang menunjukkan bahwa pada bulan pertama tidak berpengaruh, namun mulai pada bulan ketiga menunjukan tren yang menurun dari kontribusi sebesar 2,30\%. Dari bulan keempat kontribusi SBIS terhadap tingkat ROA turun secara berangsurangsur sampai pada akhir pengamatan.

NPF menunjukkan kontribusi pada pada tingkat ROA yang terus menurun dari bulan kedua sampai bulan kesepuluh. Kontribusi NPF terhadap tingkat ROA tidak ada pada bulan pertama, namun pada bulan kedua menunjukkan kontribusi sebesar 0,99\%. Periode berikutnya kontribusi NPF terhadap ROA mengalami peningkatan setiap bulannya sampai akhir pengamatan kesempuluh. Tren kontribusi, BOPO terhadap tingkat ROA tidak jauh beda dengan tren penurunan yang terjadi pada NPF terhadap tingkat ROA. Pada bulan pertama tidak ada kontribusi BOPO terhadap tingkat ROA, namun kemudian pada bulan ketiga kontribusi BOPO terhadap tingkat ROA menurun berangsur-angsur sampai pada bulan kesepuluh.

Kontribusi FIN terhadap tingkat ROA pada bulan kedua sampai kesempuluh mengalami fluktuasi. Pada bulan kedua sampai menunjukkan kontribusi FIN terhadap tingkat ROA meningkat sampai pada bulan kelima dengan nilai sebesar 0,55\%. Namun pada bulan-bulan berikutnya kontribusi FIN terhadap ROA berangsur menurun sampai akhir bulan ke sepuluh. DPK dengan FIN memiliki kontribusi rata-rata yang hampir sama terhadap ROA. Kontribusi DPK cenderung mengalami penurunan pada bulan kelima walaupun sempat fluktuatif pada periode kedua sampai keempat. Setelah pada bulan kelima dengan nilai kontribusi sebesar 0,37\%, kontribusi FIN berangsur-angsur turun sampai akhir periode kesepuluh. 
Heri Sudarsono

TBH memiliki kontribusi rata-rata yang terendah pada ROA dibanding dengan variabel yang lain. Dilihat dari tren kontribusi terhadap tingkat ROA menunjukkan nilai kontribusi TBH meningkat sampai bulan keempat, namun kemudian pada bulan berikutnya menunjukan kontribusi TBH ke ROA cenderung mengalami fluktuasi dari bulan keempat sampai pada akhir bulan kesepuluh. Rendahnya nilai tren pada setiap bulan pengamatan menunjukkan bahwa manajemen bank syariah tidak begitu terpengaruh oleh TBH untuk meningkatkan besaran ROA.

\section{Simpulan}

Hasil penelitian menunjukkan bahwa dalam jangka panjang variabel DPK, TBH, FDR berpengaruh negatif terhadap tingkat ROA, sedangkan FIN dan BOPO berpengaruh positif terhadap ROA. Berbeda dengan variabel yang lain variabel SBIS dan NPF tidak berpengaruh terhadap ROA dalam jangka panjang. Temuan ini menunjukkan bahwa manajemen bank syariah dalam menentukan besaran ROA dipengaruhi oleh tingkat DPK, TBH, FDR, FINA dan BOPO. Diantara lima variabel tersebut yang paling berpengaruh adalah BOPO disusul dengan FDR. Sedangkan variabel yang terendah memengaruhi ROA adalah SBIS dan NPF. Temuan ini menunjukkan bahwa manajemen sangat memperhitungkan tingkat kemampuan bank untuk mengelola DPK, TBH, FDR, FIN dan BOPO untuk memengaruhi ROA.

Dalam jangka pendek, variabel yang berpengaruh terhadap ROA adalah ROA sebelumnya dan FDR. Variabel DPK, FIN, SBIS, TBH, NPF dan BOPO CAR tidak berpengaruh dalam jangka pendek. Hasil ini memperlihatkan bahwa dalam jangka pendek manajemen bank syariah memperhatikan besaran pembiayan di dasarkan pada kebijakan ROA sebelumnya. Manajemen bank syariah memperhitungkan besaran ROA yang menjadi dasar menentukan kebijakan ROA di masa depan. Sementara itu, pengaruh FDR terhadap ROA bisa diartikan bahwa FDR dalam jangka pendek dijadikan sumber informasi yang penting bagi manajemen bank syariah untuk 
meoptimalkan kemampuan aset bank syariah untuk memperoleh mendapatkan yang maksimal.

Hasil impulse response menunjukkan guncangan yang terjadi pada ROA, FIN, FDR, NPF dan BOPO direspon positif oleh ROA dan akan stabil dalam jangka waktu yang berbeda pada setiap variabel. Guncangan yang terjadi pada variabel lainnya seperti tingkat DPK, SBIS dan TBH direspon negatif oleh ROA dan akan stabil pada periode yang berbeda-beda. Sedangkan hasil dari variance decomposistion menunjukkan bahwa ROA memiliki kontribusi lebih besar dari variabel FDR, SBIS, NPF, BOPO, FINA dan DPK dalam memengaruhi besarnya pembiayaan. TBH memiliki kontribusi terendah dalam memengaruhi besaran pembiayaan dibanding variabel lain. Seperti diketahui variasi data TBH relatif memiliki tren nilai kontribusi terendah dibanding variabel lain terhadap ROA. Rendah kontribusi TBH bisa diartikan bahwa manajemen bank syariah kurang memperhatikan nilai tren kontribusi TBH terhadap ROA.

Dari hasil temuan penelitian ini dapat direkomendasikan bahwa penelitian berikutnya tidak hanya variabel kinerja keuangan bank syariah tetapi juga variabel ekonomi makro perlu dimasukkan sebagai penentu tingkat ROA. Di samping itu, penggunaan metode VAR dengan kausalitas perlu dilakukan untuk meneliti pengaruh sebab akibat antar variabel terhadap tingkat ROA.

\section{Daftar Pustaka}

Amalia, Nur. 2016. "Struktur Pembiayaan dan Pengaruhnya terhadap Profitabilitas Bank Muamalat Indonesia dan Bank Syariah Mandiri." Jurnal Ilmu dan Riset Akuntansi 5 (5). https://ejournal.stiesia.ac.id/jira/ article/view/1704.

Armereo, Crystha. 2015. "Analisis Faktor-Faktor yang Mempengaruhi Profitabilitas Bank Syariah yang Terdaftar di Bursa Efek Indonesia." Jurnal Ekonomi Global Masa Kini 6 (2). http://ejournal.uigm.acid/ index.php/EGMK/article/view/65.

Economica: Jurnal Ekonomi Islam - Volume 8, Nomor 2 (2017)

http://journal.walisongo.ac.id/index.php/economica 
Heri Sudarsono

Hanania, Luthfia. 2015. "Faktor Internal dan Eksternal yang Mempengaruhi Profitabilitas Perbankan Syariah dalam Jangka Pendek dan Jangka Panjang." Perbanas Review 1 (1). http://jurnal.perbanas.id/index.php/ JPR/article/view/14.

Muh. Sabir. M, Muhammad Ali, Abd. Hamid Habbe. 2012. "Pengaruh Rasio Kesehatan Bank terhadap Kinerja Keuangan Bank Umum Syariah dan Bank Konvensional di Indonesia." Jurnal Analisis 1 (1): 79-86.

Muhaemin, Ahmad, and Ranti Wiliasih. 2016. "Analisis Faktor-Faktor yang Memengaruhi Profitabilitas Bank Pembiayaan Rakyat Syariah di Indonesia" 2 (1): 180-206. http://ojs.unida.ac.id/index.php/JN/article/ view/255.

Mulyaningsih, Sri, and Iwan Fakhruddin. 2016. "Pengaruh Non Performing Financing Pembiayaan Mudharabah dan Non Performing Financing Pembiayaan Musyarakah terhadap Profitabilitas pada Bank Umum Syariah di Indonesia." Media Ekonomi 16 (1). http://jurnalnasional. ump.ac.id/index.php/MEDEK/article/view/1282.

Rizkita Alhamditia, Era, and Mohamad Heykal. 2013. "Analisis Estimasi dan Faktor-Faktor yang Memengaruhi Tingkat Profitabilitas Bank Umum Syariah di Indonesia (Studi Kasus PT Bank Syariah Mandiri Periode 2008-2011)." Binus Business Review 4 (1): 186. https://doi.org/ 10.21512/bbr.v4i1.1046.

Sudiyatno, Bambang, and Jati Suroso. 2010. "Analisis Pengaruh Dana Pihak Ketiga, BOPO, CAR dan LDR terhadap Kinerja Keuangan pada Sektor Perbankan yang Go Public di Bursa Efek Indonesia (BEI) (Periode 20052008)." Dinamika Keuangan Dan Perbankan 2 (2). https://www.unisbank.ac.id/ojs/index.php/fe1/article/view/187.

Ubaidillah. 2017. "Analisis Faktor-Faktor yang Mempengaruhi Profitabilitas Bank Syariah di Indonesia." El-Jizya: Jurnal Ekonomi Islam 4 (1): 1510188. https://doi.org/10.24090/ej.v4i1.2016.pp1510188.

Ummah, Fathya Khaira, and Edy Suprapto. 2015. "Faktor-Faktor yang Mempengaruhi Profitabilitas pada Bank Muamalat Indonesia." Jurnal Ekonomi Dan Perbankan Syariah 3 (2): 1-24. http://jurnal.sebi.ac.id/ index.php/jeps/article/view/15. 
Wibowo, Edhi Satriyo, and Muhammad Syaichu. 2013. "Analisis Pengaruh Suku Bunga, Inflasi, CAR, BOPO, NPF terhadap Profitabilitas Bank Syariah." Diponegoro Journal of Management 2 (2): 10-19. https://ejournal3.undip.ac.id/index.php/djom/article/view/2651.

Yuliani. 2007. "Hubungan Efisiensi Operasional dengan Kinerja Profitabilitas pada Sektor Perbankan yang Go Publik di Bursa Efek Jakarta." Jurnal Manajemen Bisnis Sriwijaya 5 (10): 15-43.

Yusuf, Muhammad Yasir, and Wan Sri Mahriana. 2016. "Faktor-Faktor yang Mempengaruhi Tingkat Profitabilitas Bank Pembiayaan Rakyat Syariah (BPRS) di Aceh." Iqtishadia: Jurnal Kajian Ekonomi dan Bisnis Islam 9 (2): 246. https://doi.org/10.21043/iqtishadia.v9i2.1731. 
